\title{
Evidence for prehistoric coseismic folding along the Tsaotun segment of the Chelungpu fault near Nan-Tou, Taiwan
}

\author{
Ashley R. Streig, ${ }^{1,2}$ Charles M. Rubin, ${ }^{1}$ Wen-Shan Chen, ${ }^{3}$ Yue-Gau Chen, ${ }^{3}$ \\ Long-Sheng Lee, ${ }^{3}$ Stephen C. Thompson, ${ }^{2,4}$ Chris Madden, ${ }^{5}$ and Shih-Ting Lu ${ }^{6}$ \\ Received 7 May 2006; revised 12 December 2006; accepted 4 January 2007; published 24 March 2007.
}

[1] Taiwan's $1999 M_{w} 7.6$ earthquake generated over $85 \mathrm{~km}$ surface rupture along the Chelungpu thrust fault. Paleoseismic studies at the Shi-Jia site near Nantou city, reveal folding as the predominant form of deformation. Stratigraphic relations across the 1999 fold scarp show the style and degree of deformation caused by the penultimate event is similar to observed 1999 deformation. A boring transect across the fold scarp provides additional evidence of an earlier earthquake. Investigations at the Shi-Jia site revealed three prehistoric events; accelerator mass spectrometry (AMS) radiocarbon ages indicate that the penultimate earthquake occurred between 1160 and 1440 A.D. Paleoseismic studies north of the Shi-Jia site reveal much younger penultimate earthquakes, suggesting a 1999-type event may not be characteristic along the Tsaotun segment of the Chelungpu fault.

Citation: Streig, A. R., C. M. Rubin, W.-S. Chen, Y.-G. Chen, L.-S. Lee, S. C. Thompson, C. Madden, and S.-T. Lu (2007), Evidence for prehistoric coseismic folding along the Tsaotun segment of the Chelungpu fault near Nan-Tou, Taiwan, J. Geophys. Res., 112, B03S06, doi:10.1029/2006JB004493.

\section{Introduction}

[2] The 21 September 1999, $M_{w}$ 7.6 Chi-Chi, Taiwan earthquake was one of the largest magnitude continental reverse fault earthquakes of the 20th century. Well-exposed surface faulting and coseismic folding accompanied the 1999 Chi-Chi earthquake. The past rupture history of the Chelungpu fault is a key component for characterizing its rupture processes. This study presents findings of a history of coseismic fold growth near Nan Tou, Taiwan and compares the ages of penultimate events and style of deformation observed at the site along the central section, Tsaotun segment of the Chelungpu fault. We discuss kinematics of coseismic fold growth at the study site.

\section{Geologic Setting}

[3] Taiwan is located on the collisional boundary between the Philippine Sea plate and the Eurasian plate (Figure 1). The Philippine Sea plate is moving in a northwesterly direction relative to the Eurasian plate at a rapid rate of about $82 \mathrm{~mm} / \mathrm{yr}$ [Yu et al., 1997]. Compression across the island is accommodated by a system of strike slip and

\footnotetext{
${ }^{1}$ Department of Geological Sciences, Central Washington University, Ellensburg, Washington, USA.

${ }^{2}$ Now at William Lettis \& Associates, Inc., Walnut Creek, California, USA.

${ }^{3}$ Department of Geosciences, National Taiwan University, Taipei, Taiwan.

${ }^{4}$ Department of Geological Sciences, University of Oregon, USA.

${ }^{5}$ Earth Consultants International, Tustin, California, USA.

${ }^{6}$ Central Geological Survey, Taipei, Taiwan.
}

reverse faults (Figure 2). Prior to 1999, the largest reverse fault ruptures on the island occurred in 1935 along the northern part of the Shihtan fault, and in 1951 along the Longitudinal Valley fault [Bonilla, 1975]. Significant historical earthquakes on other oblique strike-slip faults occurred in 1906 and 1941 (the M 7.1 Chiayi earthquakes), and 1946 Hsinhua (M 6.3 earthquake) [Bonilla, 1975; Ma et al., 1999].

[4] The 1999 Chi-Chi earthquake generated over $85 \mathrm{~km}$ of surficial offsets (Figure 2) and caused the loss of over 2300 lives and over 14 billion dollars in damage [Shin et al., 2000; Lee et al., 2002]. The rupture nucleated at a depth of about 8 to $10 \mathrm{~km}$ near the southern terminus of the Chelungpu fault (CLPF) and propagated upward and northward [Ma et al., 2000; Yue et al., 2005]. This earthquake complexly ruptured the Chelungpu fault along four fault segments; Cholan, Shikang, Tsaotun, and Chushan, listed from north to south (Figure 2) [Chen et al., 2001]. Rupture on the Shikang, Tsaotun, and Chushan segments occurred on a north striking, west verging reverse fault that places Pliocene marine fine-grained mudstone and shale (Chinshui shale formation) over late Pleistocene to Holocene gravel and sand [Lee et al., 2002]. This is the westernmost active thrust fault that daylights with continuous surface expression on the island. West of the CLPF is the frontal fault of the Taiwan range, the concealed Chang-Hua fault that forms the Paukashan anticline.

[5] Coseismic reverse slip on the southern Chushan and central Tsaotun fault segments was commonly greater than $1.5 \mathrm{~m}$ [Chen et al., 2001]; vertical and horizontal offsets on the Shikang and Cholan segments were much larger, aver-

Copyright 2007 by the American Geophysical Union. 0148-0227/07/2006JB004493\$09.00 


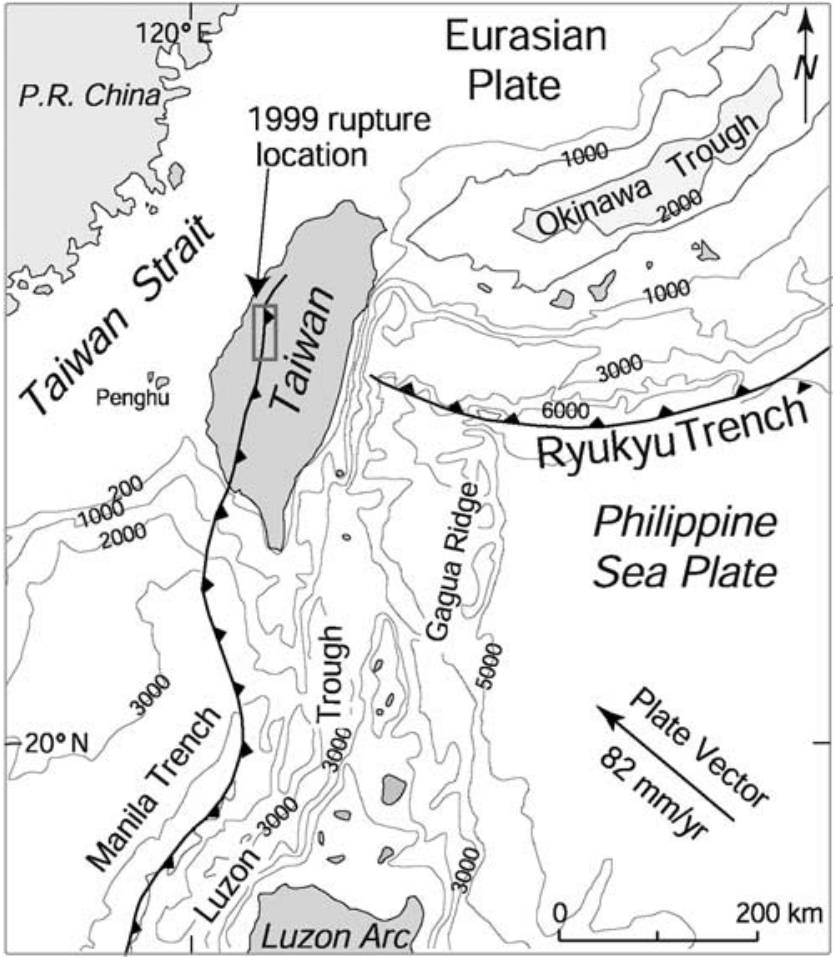

Figure 1. Bathymetry of the Taiwan region, showing the western termination of the Ryukyu trench east of Taiwan and the northern termination of the active Manila trench in the western Taiwan fold-and-thrust belt. Modified from Suppe [1984, 1987] with permission. Plate vector direction and rate between Philippine Sea and Eurasian Plate from $\mathrm{Yu}$ et al. [1997].

aging 5-6 $\mathrm{m}$ with values as high as $10 \mathrm{~m}$ of vertical offset on the Shikang segment (Figure 2) [Chen et al., 2001].

\section{Shi-Jia Site}

[6] The Shi-Jia site is on the southern portion of the Tsaotun segment of the CLPF, near Nantou city (Figure 2). We excavated a single trench across the 1999 surface rupture where the CLPF crosses a small alluvial fan near the base of the Western Foothills (Figure 3). Here, the 1999 rupture follows the frontal expression of Western Foothills [Chen et al., 2001]. The amount of vertical slip along this segment of the fault ranged from 0.5 to $3.0 \mathrm{~m}$. At the Shi-Jia site a total of $1.6 \pm 0.1 \mathrm{~m}$ of measured vertical displacement was accommodated entirely by folding, the fault rupture did not propagate to the surface. Aerial photographs, taken in 1976, show preexisting fault scarps that closely match the 1999 fault rupture and suggest a prior history of faulting.

[7] Alluvial fan aggradation occurs across the trench site by debris flows and fluvial overbank and channel facies from ephemeral streams. Sediment supply in the alluvial fan is derived from the adjacent foothills which contain Chinshui shale and well-sorted Pliocene quartz sandstone. The alluvial fan is bounded on the west by the larger meandering Mao Lo Shi river (Figure 3).

[8] The west vergent CLPF has displaced, east side up, several terraces and three alluvial surfaces that we identify based on field mapping and interpretation of aerial and orthophotos. These surfaces are, from the highest to the lowest elevation, $\mathrm{Qt}_{1}, \mathrm{Qal}_{1}, \mathrm{Qal}_{2}$, and $\mathrm{Qal}_{3}$, respectively (Figure 3). For the purposes of this study we have only mapped the youngest terrace observed, $\mathrm{Qt}_{1}$, the presence of terraces in the area are evidence of a long history of uplift. The $\mathrm{Qt}_{1}$ surface is $120 \mathrm{~m}$ above sea level, highly dissected and discontinuous (Figure 3). Three alluvial surfaces were identified, $\mathrm{Qal}_{1}, \mathrm{Qal}_{2}$, and $\mathrm{Qal}_{3}$. The $\mathrm{Qal}_{1}$ surface is bounded to the west by a linear fault scarp and to the east by the mountain front (Figure 3 ). Profiles across the site show an inflection in topography, interpreted as an older linear fault scarp, at the western edge of $\mathrm{Qal}_{1}$ (Figure 4). The 1999 earthquake uplifted the $\mathrm{Qal}_{2}$ surface, raising it vertically $1.6 \pm 0.1 \mathrm{~m}$ on the hanging wall. Two profiles across the Shi-Jia site show vertical separation from the 1999 event between the footwall and the hanging wall in the $\mathrm{Qal}_{2}$ surface (Figure 4). Further studies of the terraces in the area

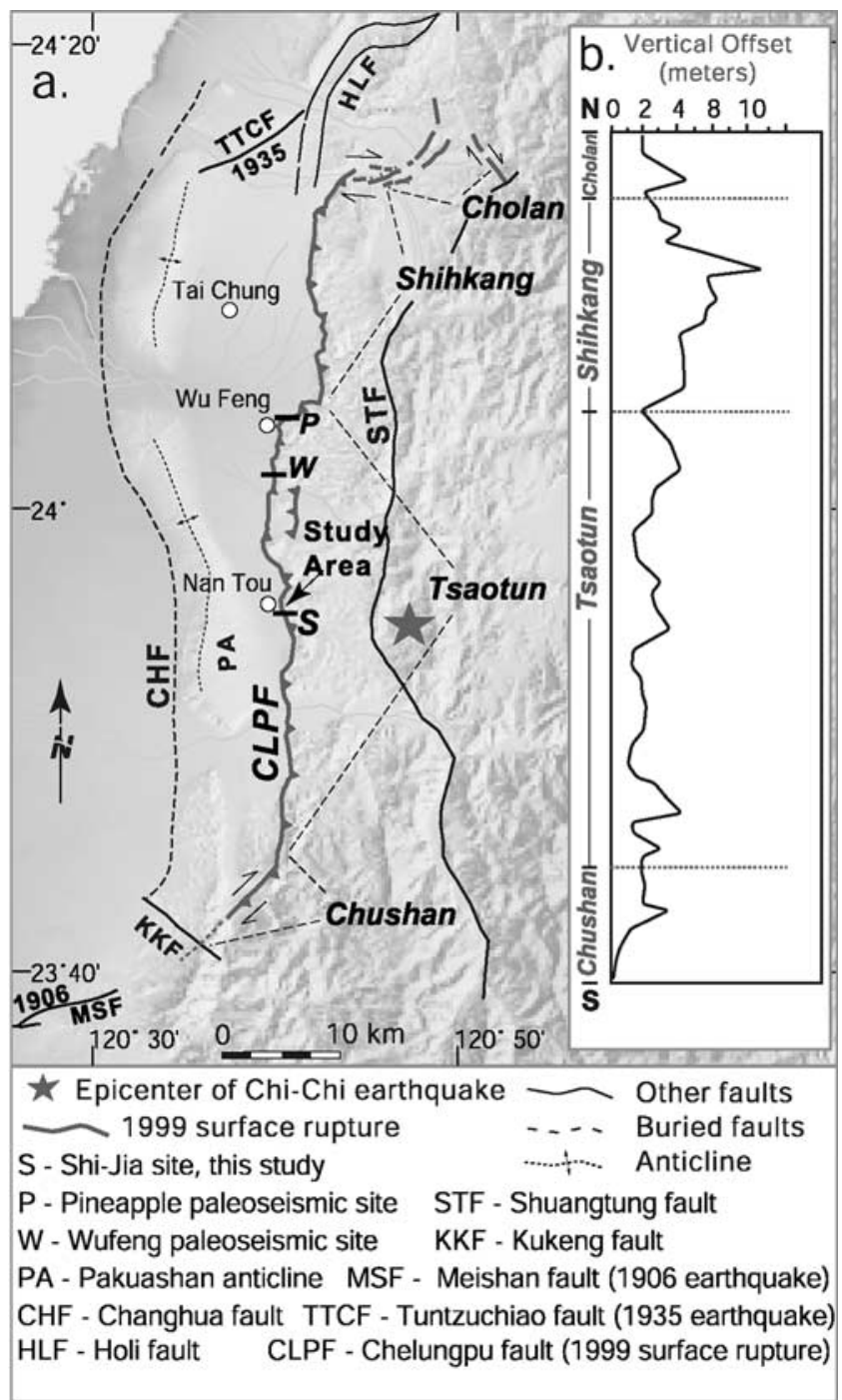

Figure 2. (a) Map of the 1999 surface rupture and major neighboring faults. Locations of three paleoseismic study sites are shown on the Tsaotun segment; Shi-Jia site (this study), Pineapple and Wufeng sites. (b) Field observations of vertical offsets. From Rubin et al. [2001]. 


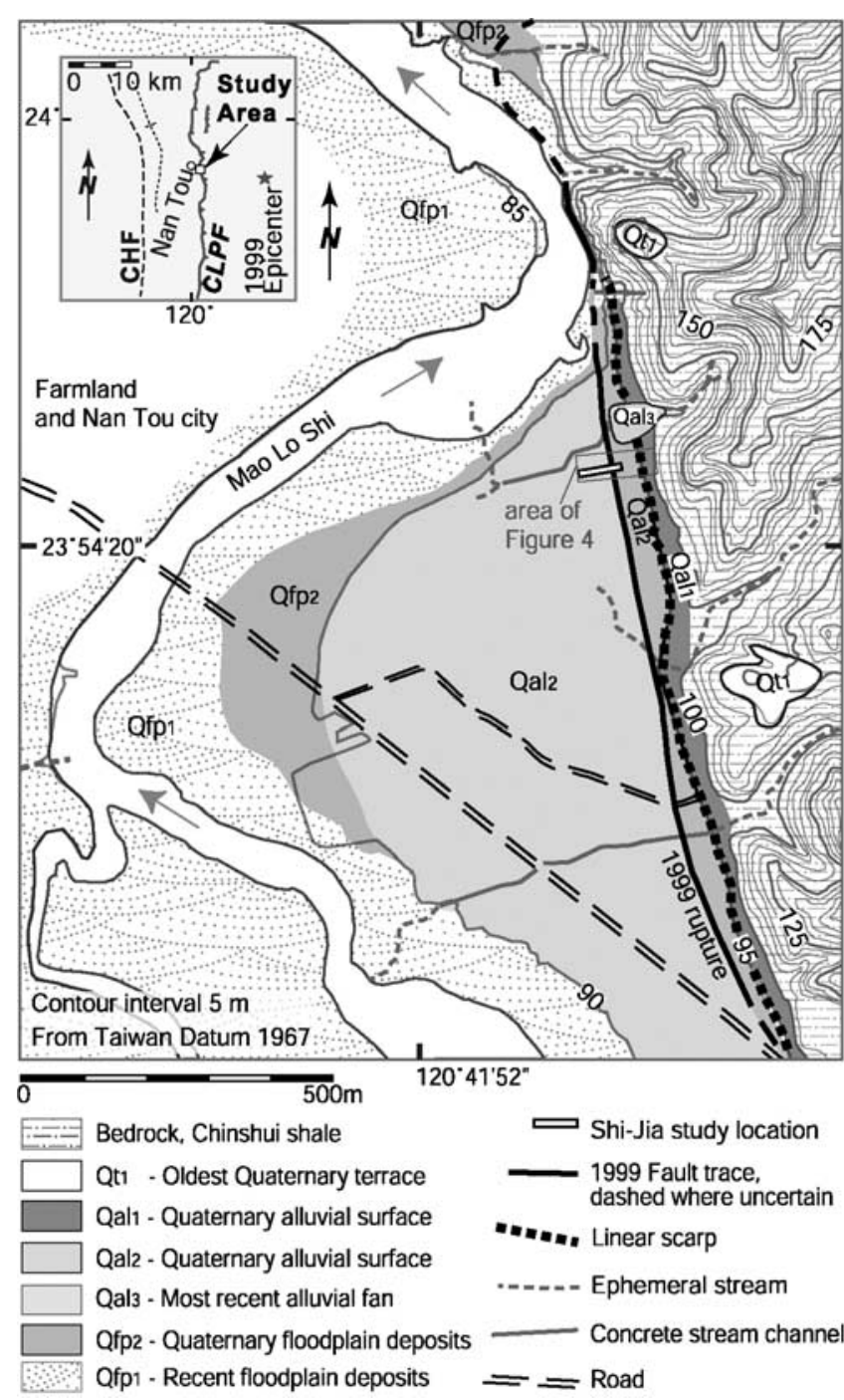

Figure 3. Quaternary geologic map of the study area. The 1999 fault scarp is shown as a heavy black line west of the mountains. The Shi-Jia trench site is shown as a small white box crossing the mapped trace of the 1999 rupture. A second linear scarp is mapped east of the 1999 rupture. This scarp bounds the western edge of the $\mathrm{Qal}_{1}$ surface. The mountain front bounds the eastern edge of the $\mathrm{Qal}_{1}$ surface. Trench sediments are interpreted as mudflow deposits from the mountain front and overbank deposits from the small ephemeral stream directly north of study location, on the $\mathrm{Qal}_{3}$ surface. Mao Lo Shi flows in a northward direction, floodplain deposits are below 90 m elevation.

are needed to develop a better understanding of the relationship between the ages of the fluvial terraces and long-term uplift by the CLPF.

[9] The Shi-Jia site was identified as an ideal paleoseismic study site because the ground surface was not modified after 1999, and the betel nut (Areca catechu palm) orchard on the site was abandoned soon after the earthquake. The site was a good distance from a local tributary to the Mao Lo Shi river which ensured a fine grain sediment source and far enough that there would be minimal channel deposits cutting stratigraphy. The Shi-Jia trench was excavated across and perpendicular to the 1999 scarp and oriented $\mathrm{N} 80^{\circ} \mathrm{E}$. The excavation totaled $51 \mathrm{~m}$ length and $5 \mathrm{~m}$ depth. Trench walls were mapped on a $1 \times 0.5 \mathrm{~m}$ grid using high-resolution photographs at a scale of $1: 10$. The trench and alluvial surfaces were surveyed using a total station (Figure 4).

[10] A transect of four boreholes was drilled across the 1999 fold scarp to delineate older stratigraphic units, measure total vertical displacement of units at depth across the fold scarp, better define the fold geometry beneath the site and to locate the fault plane. Two boreholes were located on the backlimb of the fold and two on the forelimb, and extended to a depth of $50 \mathrm{~m}$ (Figure 5).

\section{Results}

\subsection{Stratigraphic Relations}

[11] The Shi-Jia trench exposed a sequence of overbank fine-grained sediment with incipient to strong soil development. These soils provide evidence of landscape stability. Stratigraphic units were distinguished by color, lithology, degree of soil development, and bioturbation. We group strata exposed in boreholes and trenches into twenty stratigraphic packages. These packages are numbered from oldest to youngest with unit 1 consisting of bedrock Chinshui shale and unit 5, Pleistocene to Holocene cobbles encountered in boreholes. Stratigraphic units 7 to 80 are packages of interbedded overbank and fluvial deposits. Units 90 through 170 consist of overbank fine silt. Detailed unit descriptions are shown in Table 1.

[12] The stratigraphic succession exposed in the boreholes and excavation was floored by Pleistocene to Holocene alluvial cobble gravels, labeled unit 5. Pliocene marine Chinshui shale, unit 1 , is observed stratigraphically higher than unit 5, in the northeast end of the trench (backlimb). Sandy silt with fine laminations, unit 7 , unconformably caps unit 5, alluvial gravels. This sandy silt unit marks the transition to fine grained alluvial deposits from a new sediment source, uplifted Chinshui shale mountain front. Overall, upward coarsening stratigraphic succession of trench sediments reflect movement of ephemeral streams across the alluvial surface, or a change in the fluvial system.

\subsubsection{Borehole Sediments}

[13] The oldest strata identified at the site, unit 1 , is dull light gray, very weakly cohesive, Pliocene Chinshui shale. Boreholes $\mathrm{C} 1$ and $\mathrm{C} 2$, located east of the scarp, encountered the top if Chinshui shale at depths of 11.0 and $9.7 \mathrm{~m}$, respectively. In both boreholes, the Pliocene shale overlies late Quaternary cobble gravels, unit 5. These cobble gravels are probably late Pleistocene to Holocene in age, based on correlative strata exposed on the hanging wall of the CLPF [Chen et al., 2001]. Chinshui shale is not exposed in boreholes $\mathrm{C} 3$ and $\mathrm{C} 4$, west of the fold scarp. In borehole $\mathrm{C} 4$, the top of the cobble gravel, unit 5, was encountered at a depth of about $8 \mathrm{~m}$ and continued to the maximum depth explored, about $50 \mathrm{~m}$. Overlying the cobble gravels is dark gray slightly sandy silt, borehole unit 7 (Table 1). It is normally graded, with very fine planar clay laminations interbedded in the upper $0.1 \mathrm{~m}$ of the sequence. Conform- 


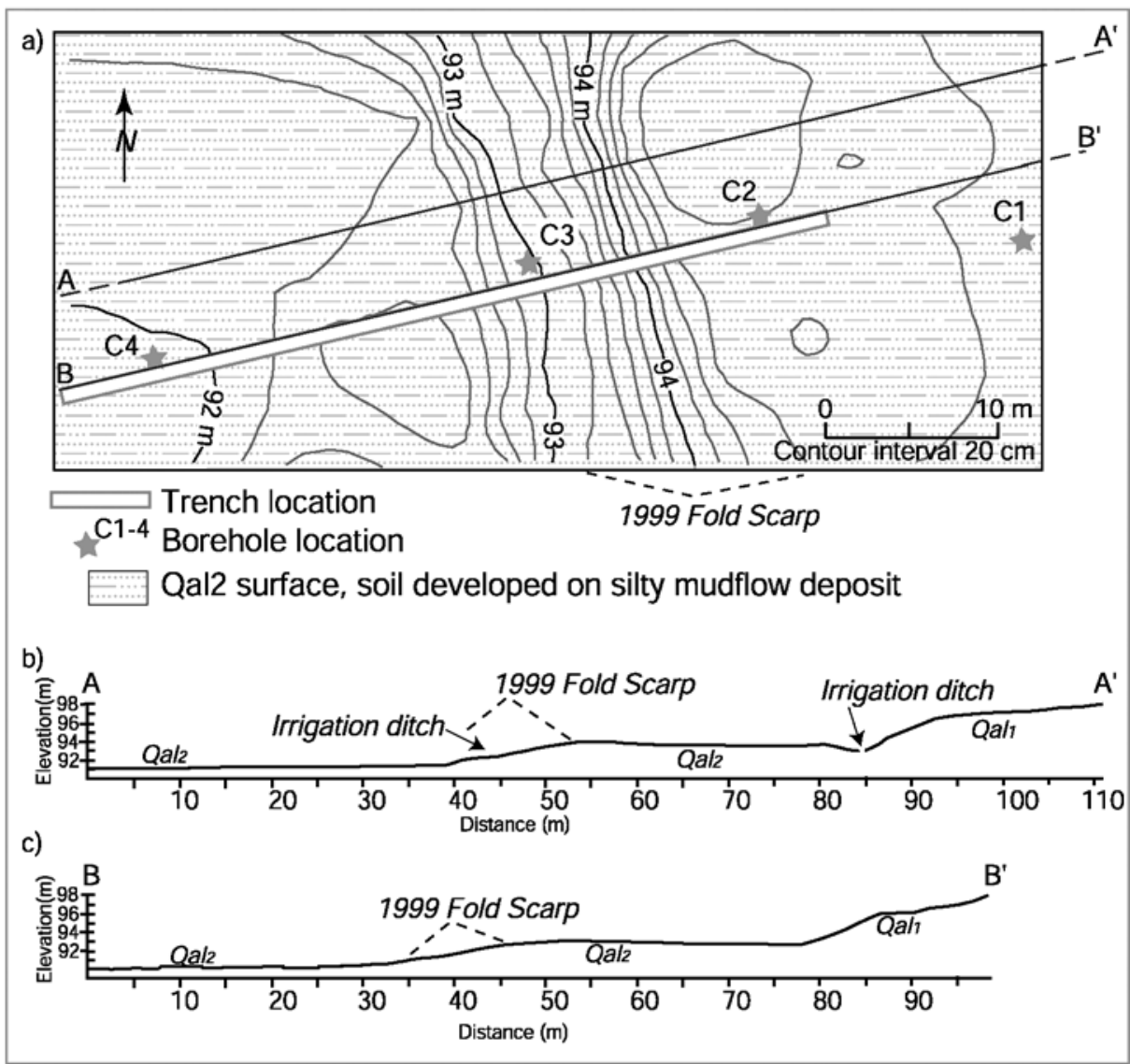

Figure 4. (a) Detailed topographic map and profiles of Shi-Jia site. Locations of trench, borings, and profiles were surveyed using an electronic EDM/theodolite. The 1999 vertical separation was $1.6 \pm 0.1 \mathrm{~m}$; the fold scarp strikes N10 ${ }^{\circ} \mathrm{W}$. (b) Profile across 1999 fold scarp through Shi-Jia field, A-A'. The ground surface has been slightly modified since 1999 . An irrigation ditch was added along the base of the fold scarp and an existing ditch was enhanced above the 1999 scarp and along an older scarp. Geomorphic surfaces from Figure 3 are labeled on the profiles: $\mathrm{Qal}_{2}$ and $\mathrm{Qal}_{1}$. The 1999 scarp separates $\mathrm{Qal}_{2}$ on the hanging wall and footwall of the fault. An older scarp separates $\mathrm{Qal}_{1}$ and $\mathrm{Qal}_{2}$. (c) Profile across 1999 fold scarp, along north wall of trench, B-B'.

ably overlying borehole unit 7 is trench unit 10 (shown in borehole $\mathrm{C} 1$, Figure 5).

\subsubsection{Trench Sediments}

[14] Unit 10, at a depth of $5.5 \mathrm{~m}$, is the oldest unit exposed in the trench. Unit 10 is a massive silty clay derived from a low-energy pond environment, possibly on the alluvial floodplain (Table 1).
[15] Units 20, 30, and 40 are massive, very fine sand and silt. Laminations and lenses of very fine sand suggest that units 20 to 40 are overbank sediments deposited by a proximal stream during a flood. The probable source of these deposits is a small ephemeral stream located just north of the excavation (Figure 3 ).

[16] Unit 50 consists of interbedded mudflow and overbank stream deposits. Unit 60 is fine-grained sand to silty

Figure 5. Detailed map of the north trench wall and borings across the Chelungpu fold scarp. Fault location is projected between borings $\mathrm{C} 1$ and $\mathrm{C} 2$ and has a dip of $27 \pm 2^{\circ}$. The uppermost gray unit, unit 190, is human modified material, though the surface has not been modified since the 1999 rupture. Unit 190 truncates unit 150 at $2 \mathrm{~m}$ east of the small pop-up structure; thickness here is similar to thickness on the lower fold limbs. Unit 150 displays constant thickness, suggesting an overlapping relationship with unit 100 . The modern ground surface displays $1.6 \pm 0.1 \mathrm{~m}$ of vertical separation across the fold. Vertical separation of units 90 and 100 across the fold is $3 \mathrm{~m}$. The penultimate event horizon is interpreted between the first continuous unit across the fold scarp, unit 100, and the overlying sequence of onlap sediments, beginning with unit 110. Secondary faults are shown in red, notice bedding parallel shear planes and pop-up structure. Centimeters to millimeters of offset are observed on these structures. Paleosol horizons are distinguished within the respective units: vertical white lines show location of soil A horizons, slanted white lines show location of B horizons. Cross-bedded and laminar sands are shown, as mapped, in situ. No vertical exaggeration. 


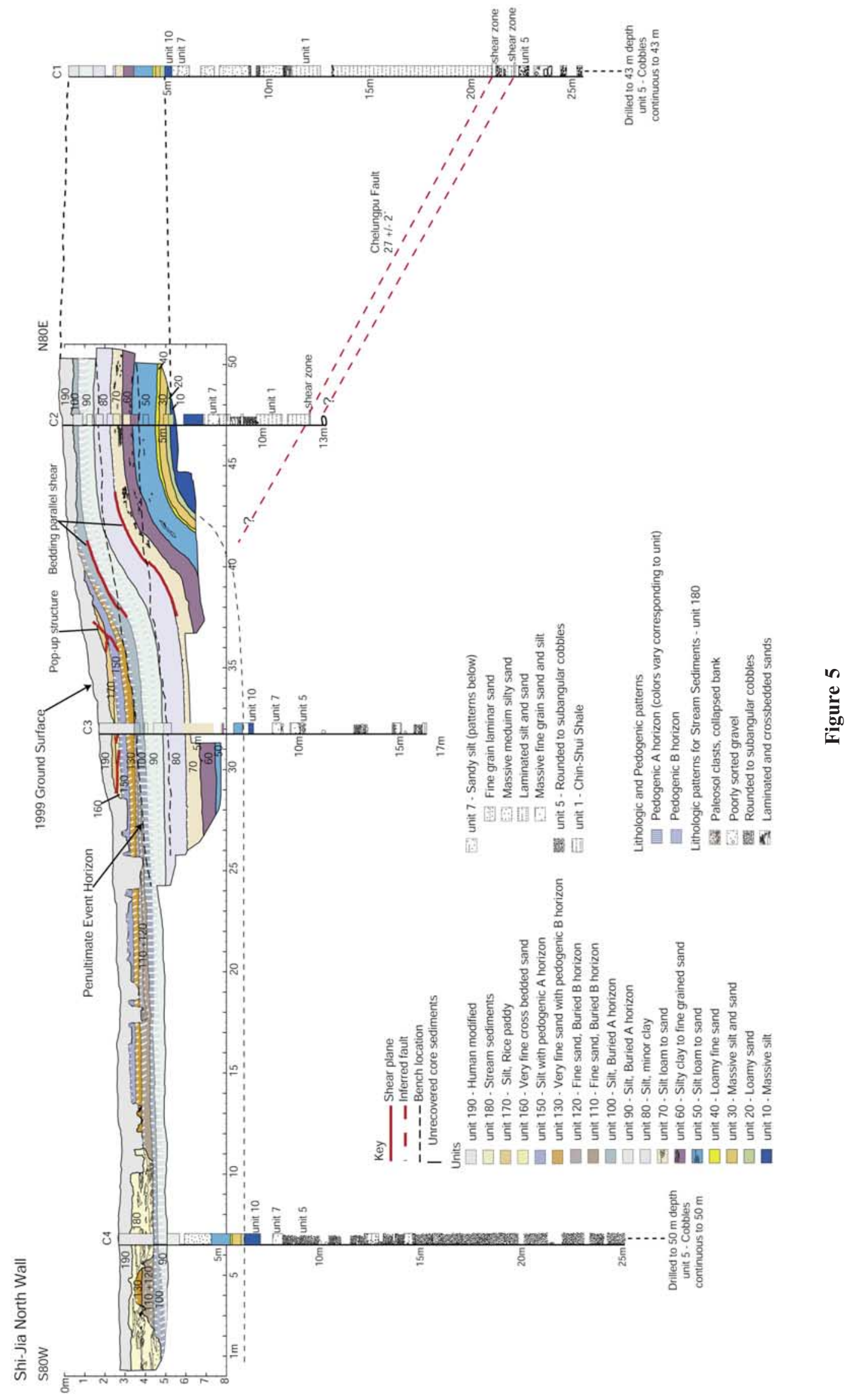


Table 1. Unit Descriptions

\begin{tabular}{|c|c|c|}
\hline Unit Sequence & Description $^{\mathrm{a}}$ & Depositional Environment \\
\hline 1 & Pliocene Chinshui shale, dull, light gray, very weakly cohesive & offshore marine \\
\hline 5 & Quaternary cobble gravels, poorly consolidated, clast supported & terrestrial deposit \\
\hline 7 & $\begin{array}{l}\text { silt, slightly sandy, dark gray, normally graded, } \\
\text { very fine planar clay laminations interbedded in the upper } 0.1 \mathrm{~m}\end{array}$ & low-energy pond \\
\hline 10 & $\begin{array}{l}\text { silty clay, dark bluish gray, massive, well-sorted, } \\
\text { with lenses of very fine silty sand; some plant bioturbation and } \\
\text { root casts; conformable basal contact }\end{array}$ & $\begin{array}{l}\text { low-energy pond environment, } \\
\text { possibly on the alluvial floodplain }\end{array}$ \\
\hline $20,30,40$ & $\begin{array}{l}\text { silt with very fine sand, greenish gray, massive, locally discontinuous } \\
\text { very fine silt and sand laminae in lower halves of units } 20 \text { and } 40 \text {; } \\
\text { unit } 30 \text { contains very well sorted lenses of very fine grained sand; } \\
\text { Bwb soil developed on upper } 3 \mathrm{~cm} \text { of unit } 40 \text {; depositional basal contacts. }\end{array}$ & $\begin{array}{l}\text { overbank sediments deposited } \\
\text { by a proximal stream during } \\
\text { a flood }\end{array}$ \\
\hline 50 & $\begin{array}{l}\text { silt with clay and sand, base of unit is well-sorted, silty sand with } \\
\text { laminated lenses; silty clay } 1-3 \mathrm{~cm} \text { thick overlies the sands; } \\
\text { this silty clay coarsens upward to massive sandy silt; inverse grading; } \\
\text { a buried soil Ab, Bwb, BCb developed on upper half of unit; } \\
\text { erosional basal contact }\end{array}$ & $\begin{array}{l}\text { interbedded mudflow and } \\
\text { overbank stream deposits }\end{array}$ \\
\hline 60 & $\begin{array}{l}\text { sand to silty clay, fine-grained sand, base of unit is silty sand, finely laminated, } \\
\text { well-sorted, few lenses of massive sand, bioturbation, fining upward sequence; } \\
\text { irregular, diffuse, wavy, discontinuous erosional basal contact }\end{array}$ & suspended load, overbank deposits \\
\hline 70 & $\begin{array}{l}\text { sand, well-sorted, fine-grained, cross-bedded, fining upward, weak } \\
\text { Awb soil development in upper } 10 \mathrm{~cm} \text {; conformable basal contact }\end{array}$ & stream deposits \\
\hline 80 & $\begin{array}{l}\text { silt, well-sorted, fine laminations, buried B horizon developed on upper } \\
\text { few centimeters; diffuse basal contact over several centimeters }\end{array}$ & overbank deposits \\
\hline 90,100 & $\begin{array}{l}\text { sandy silt, massive, well-sorted, some root casts, paleosol development } \\
\text { in both units } 90 \text { and } 100 \text {; unit } 90 \text { has a sharp, planar basal contact } \\
\text { with unit } 80 \text {; sharp contact between units } 90 \text { and } 100\end{array}$ & mudflow deposits \\
\hline $110,120,130$ & $\begin{array}{l}\text { loamy sand to sandy loam, coarsening upward sequence, pedogenic } \\
\text { Bb horizon is developed on the upper portion of units } 110,120 \text {, } \\
\text { and } 130 \text {; sharp basal contacts }\end{array}$ & onlap sequence of sediments. \\
\hline 150 & silt, massive, common bioturbation, pedogenic $\mathrm{Ab}, \mathrm{Bb}, \mathrm{Cb}$ horizons & overlap sequence \\
\hline 160 & sand, fine-grained, some cross beds, poorly sorted & stream deposits \\
\hline 170 & $\begin{array}{l}\text { silt, light gray, mottled color, massive, abundant very fine pores and roots; } \\
\text { sharp lower contact }\end{array}$ & rice paddy \\
\hline 180 & $\begin{array}{l}\text { sand, fine- to medium-grained, very poorly sorted, extensive pockets of } \\
\text { well-sorted laminated and cross-bedded fine to medium grained sand; } \\
\text { rip up clasts of A horizon soils, angular, } 1 \text { to } 2 \mathrm{~cm} \text { diameter; sharp basal erosional contact }\end{array}$ & stream deposits \\
\hline 190 & $\begin{array}{l}\text { silt, poorly consolidated, contains plastic, rope, and broken pottery; } \\
\text { unconformable basal contact }\end{array}$ & modern modified sediment \\
\hline
\end{tabular}

${ }^{\mathrm{a}} \mathrm{Ab}$, buried A horizon; Bwb, buried B horizon altered by weathering; $\mathrm{BCb}$, buried $\mathrm{BC}$ horizon; Awb, buried A horizon altered by weathering; $\mathrm{Bb}$, buried $\mathrm{B}$ horizon; $\mathrm{Cb}$, buried $\mathrm{C}$ horizon.

clay, fining upward. The fining upward sequence represents settling of suspended load of overbank sediments. Unit 70 is a medium energy fluvial deposit. This unit is a well-sorted, fine-grained cross-bedded sand, an overall fining upward sequence.

[17] Unit 80 is a laminar silt thickening westward. We interpret unit 80 as water lain sediments. A likely result of a series of overbank stream flows depositing thinly bedded sheets of silt across the alluvial surface [Friedman and Sanders, 1978].

[18] Units 90 and 100 are sandy silt units that thicken toward the west. The lack of bedding structure and massive character of the sediment suggest that units 90 and 100 are mudflow deposits, derived from the fine-grained Chinshui shale exposed along the mountain front directly east of the site. The upper surface of unit 100 is human modified on the east end of the excavation (Figure 5).

[19] Units 110, 120, and 130 coarsen upward from loamy sand to sandy loam. These units taper toward the east, in the direction of the fold scarp (Figure 5). Beginning with unit 110 each successive wedge-shaped unit terminates farther eastward against unit 100. These units onlap unit 100 (Figure 5).
[20] Unit 150 is massive silt with pedogenic development. This unit is $37 \mathrm{~cm}$ thick along the forelimb of the fold. The eastern portion of unit 150 is modified, as shown in Figure 5. Because of its slow eastward tapering thickness, we interpret unit 150 as overlapping unit 100 prior to human modification.

[21] Unit 160 is a faintly cross-bedded very fine grained sand. This unit is likely correlative with young stream sediments, unit 180, found at the western end of the trench. Unit 170 is massive light gray mottled silt, contrasting greatly in color from other units. Very common mottles, fine roots and pores are remnant of shallow rice plant roots, the overall appearance suggests unit 170 is a buried rice paddy.

[22] Unit 180 occupies a swale incised into units 100 to 150 at the western end of the trench. Sediments in unit 180 are very poorly sorted, soil rip-up clasts are also mixed within the unit. The rip-up clasts are likely derived from the buried soil on unit 150 . Unit 180 stream deposits probably represent a recently abandoned channel of the ephemeral stream that is presently $30 \mathrm{~m}$ north of the trench (Figure 3 ). Across the site, on average, the upper 50 to $70 \mathrm{~cm}$ of sediment is modified by recent farming activities. We 


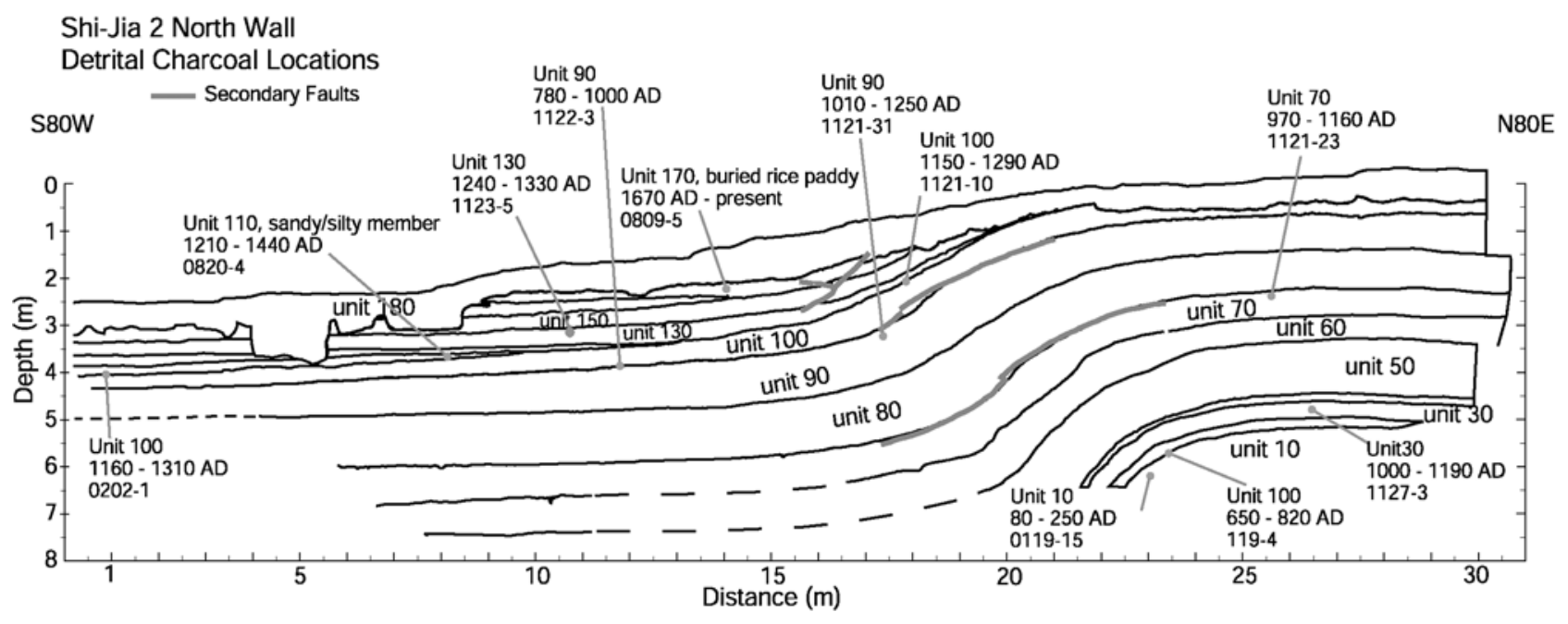

Figure 6. Location of detrital charcoal samples collected from the north wall of the Shi-Jia excavation. Sample name, calibrated age, and depth are shown here; additional values are given in Table 2.

labeled this modern modified sediment unit 190, this unit cuts all other units near the surface and contains some modern debris like plastic, rope, and broken pottery.

\subsubsection{Age Estimates}

[23] Eleven detrital charcoal samples were collected and analyzed from eight units to constrain ages of alluvial sediments exposed in the trench (Figure 6). These detrital charcoal samples indicate that all units in the trench exposures are late Holocene in age (Figure 6 and Table 2).

[24] Detrital charcoal collected from the uppermost horizon and middle of unit 10 yielded ages of $650-820$ and 80-250 A.D., respectively. A fragment of detrital charcoal from unit 30 yielded an age of 1000-1190 A.D. Detrital charcoal collected near the center of unit 70 yielded an age of 970-1160 A.D., a calibrated age that is indistinguishable from unit 30. Samples from unit 90 yielded ages of 7801000 and 1010-250 A.D.

[25] Two samples from unit 100 yield calibrated ages of 1160-1310 A.D., and 1150-1290 A.D. Rapid deposition of onlap unit 110 preserved detrital charcoal in the upper few centimeters of unit 100. The fold axis and backlimb of unit 100 were exposed to erosion and weathering for a longer period of time than the forelimb, where sediments onlapped against unit 100. Because erosion has stripped away the upper few centimeters of sediment from the fold axis and backlimb the upper horizon of unit 100 must be stratigraphically higher on the forelimb. Therefore we interpret the detrital charcoal collected from the forelimb (sample 0202-1, Figure 6) which yielded an age of 1160-1320 A.D., as stratigraphically higher within unit 100 than the sample

Table 2. Radiocarbon Analyses of Detrital Charcoal Collected From Trench Exposures

\begin{tabular}{|c|c|c|c|c|c|c|}
\hline Sample Code ${ }^{a}$ & Laboratory $^{\mathrm{b}}$ & $\begin{array}{c}{ }^{14} \mathrm{C} \text { Age } \pm 1 \sigma \\
{ }^{c} \text { years B.P. }\end{array}$ & $\begin{array}{c}\text { Calibrated Age } \\
\text { Range } \pm 2 \sigma \\
\text { d years B.P. }\end{array}$ & $\begin{array}{l}\text { Calibrated Age, } \\
\text { calendar years A.D. }\end{array}$ & Stratigraphic Unit ${ }^{\mathrm{e}}$ & $\begin{array}{c}\text { Depth Below } \\
\text { Ground Surface, m }\end{array}$ \\
\hline $0809-5$ & 80985 & $100 \pm 60$ & 280 to $\operatorname{modern}^{\mathrm{f}}$ & 1670 to present & 170 & 0.85 \\
\hline $1123-5$ & 86417 & $710 \pm 40$ & $710-620$ & $1240-1330$ & 130 & 1.5 \\
\hline $0820-4$ & 80983 & $700 \pm 60$ & $740-550$ & $1210-1440$ & 110 & 1.5 \\
\hline $0202-1$ & 86413 & $770 \pm 50$ & $790-640$ & $1160-1310$ & 100 & 1.55 \\
\hline $1121-10$ & 86412 & $810 \pm 40$ & $800-660$ & $1150-1290$ & 100 & 0.9 \\
\hline $1121-31$ & 86411 & $910 \pm 60$ & $940-700$ & $1010-1250$ & 90 & 2.5 \\
\hline $1122-3$ & 86530 & $1130 \pm 35$ & $1170-950$ & $780-1000$ & 90 & 2.2 \\
\hline $1121-23$ & 86407 & $995 \pm 40$ & $980-790$ & $970-1160$ & 70 & 2.5 \\
\hline $1127-3$ & 86399 & $955 \pm 40$ & $950-760$ & $1000-1190$ & 30 & 4.95 \\
\hline 0119-4 & 86396 & $1295 \pm 40$ & $1300-1130$ & $650-820$ & 10 & 5.75 \\
\hline $0119-15$ & 86397 & $1840 \pm 35$ & $1870-1700$ & $80-250$ & 10 & 6.16 \\
\hline
\end{tabular}

${ }^{\mathrm{a}}$ Samples listed in stratigraphic order, shown in Figure 7.

${ }^{\mathrm{b}}$ Samples prepared and run at Center for Accelerator Mass Spectrometry, Lawrence Livermore National Laboratories by G. Seitz.

${ }^{\mathrm{c}}$ The quoted age is in radiocarbon years using the Libby half-life of 5568 years and following the conventions of Stuiver and Polach [1977]; uncertainty shown is $\pm 1 \sigma$.

${ }^{\mathrm{d} C a l e n d r i c}$ ages calculated using OxCal 3.5 calibration program (C. B. Ramsey, Radiocarbon calibration program OxCal 3.5, available at http:// www.rlaha.ox.ac.uk/orau/06 ind.htm, 2000).

e Units are labeled in Figure 5, sample locations are shown in Figure 7.

${ }^{\mathrm{f}}$ Value younger than 1950 A.D. 
Table 3. Unit Thicknesses Across Fold Scarp

\begin{tabular}{lccc}
\hline & \multicolumn{3}{c}{ Thickness Values, ${ }^{\mathrm{a}} \mathrm{cm}$} \\
\cline { 2 - 4 } Unit & Backlimb & Synclinal Axis & Forelimb \\
\hline 100 & $-^{\mathrm{b}}$ & 56.0 & 49.5 \\
90 & 77.5 & 102.0 & 81.5 \\
80 & 83.5 & 132.0 & 111.0 \\
70 & 56.0 & 81.0 & 70.0 \\
\hline
\end{tabular}

${ }^{\mathrm{a}}$ Thickness measurements were recorded on northeast limb, fold axis, and southwest limb of fold in order to quantify the amount of unit thickening through the fold axis related to coseismic deformation.

${ }^{\mathrm{b}}$ No value, upper horizon modified.

collected from the fold axis which yielded an age of 1150 1290 A.D. (sample 1121-10).

[26] A sample from the base of unit 110 yielded an age range of 1210-1440 A.D. Unit 110 is the oldest unit in the onlap sequence, but yields a calibrated age indistinguishable from unit 130. Detrital charcoal from unit 130, the youngest member of the onlap sediment sequence analyzed yielded a calibrated age range from 1240 to 1330 A.D. This sample was collected below the fold scarp, stratigraphically in the center of the unit (Figure 6). Detrital charcoal collected and dated from unit 170 yielded calibrated calendar age between 1670 A.D. and present.

\subsection{Fault Location}

[27] Our trench revealed monoclinic folding of alluvial sediments at the surface of the Shi-Jia site. A series of boreholes across the site revealed the underlying fault, which enabled us to constrain the location of the fault tip. The fault was identified in extracted borehole sediments, as bands of uncharacteristically dark and highly sheared bedrock Chinshui shale.

[28] Material in the shear zone visibly differs from nonsheared Chinshui shale. Nonsheared Chinshui shale has a dull light gray color and shows pressure fluidization from drilling and extraction. Sheared material is dark gray to black. Shear zones in borehole $\mathrm{C} 1$ are $0.22,0.05$, and $0.03 \mathrm{~m}$ thick, and in borehole C2 is $0.03 \mathrm{~m}$ thick. Deformed zones are located in borehole $\mathrm{C} 1$ at a depth of 20.94-21.16 m, and $\mathrm{C} 2$ at $12.2-12.23 \mathrm{~m}$ (Figure 5). The fault is not present in boreholes $\mathrm{C} 3$ or $\mathrm{C} 4$. So the fault tip must be located at a depth greater than $6 \mathrm{~m}$ (depth of the trench), though less than $12.2 \mathrm{~m}$, and between the boreholes $\mathrm{C} 2$ and $\mathrm{C} 3$. Measurement of shear zones within the Chinshui shale in boreholes $\mathrm{C} 1$ and $\mathrm{C} 2$ indicate an east dip of $27 \pm 2^{\circ}$.

\subsection{Evidence of Earthquakes}

\subsubsection{The 1999 Chi-Chi Earthquake, $E_{0}$}

[29] A west dipping, 6-m-wide monocline strikes $\mathrm{N} 10^{\circ} \mathrm{W}$ across the Shi-Jia site, causing clear warping of rows of fruit and palm trees (Figures 3 and 4). In the surrounding area, the rupture scarp is also apparent through deformed roads, fences, and a concrete stream channel. The fold scarp records vertical separation of $1.6 \pm 0.1 \mathrm{~m}$ between upper and lower fold limbs and a maximum inclination of $\sim 11^{\circ}$ west. Prior to 1999 , the fields exhibited a gentle west dipping slope, with no surficial evidence of a scarp (personal communications from local farmers and residents). Deformation measurements at the at the nearby Tsaotun trench, just north of the Mao Lo Shi, also reveal $1.5 \mathrm{~m}$ of vertical separation following the 1999 event [Ota et al., 2001], though no penultimate event was identified at this site.

[30] Structural and stratigraphic relations in the excavation suggest that folding is the predominant form of deformation near the surface. The fault was not exposed within the trench, indicating that the fault rupture tip terminated at a depth greater than $6 \mathrm{~m}$.

[31] Four small faults in the upper $3 \mathrm{~m}$ of trench exposures are discontinuous with depth, and are the only form of reverse-brittle failure observed in the trench wall exposures relict of 1999 deformation. These secondary deformation structures include a small pop-up flower structure, and a minor thrust with a few centimeters of displacement (Figure 5). Centimeter offsets on secondary faults show these features did not accommodate much 1999 deformation. Bedding parallel slip planes are exposed below unit 100 (Figure 5). These slip planes exhibit a shear fabric and occur along the contacts between units of differing lithologies. The amount of displacement accommodated by these features was not measurable, though seemed to be at the millimeter scale. Unit thickening was also measured across the fold scarp. Unit thickness was measured perpendicular to bedding on the backlimb, forelimb and through the synclinal axis (Figure 6). We measured the greatest bedding thickness through the synclinal axis of the fold (Table 3).

\subsubsection{Penultimate Earthquake, $\mathbf{E}_{1}$}

[32] Unit 100 is the youngest stratigraphic unit displaying greater vertical separation across the fold scarp than values of vertical separation measured at this site after 1999. Unit 100 is disturbed by farming activities on the backlimb, so we could not measure vertical separation across the fold scarp without extrapolating the upper horizon of the unit. The basal contact of unit 100 with unit 90 is continuous across the fold and has about $3 \mathrm{~m}$ of vertical separation between the backlimb and forelimb, roughly $1.5 \pm 0.1 \mathrm{~m}$ greater than displacement measured from the 1999 ground surface.

[33] Units 110 to 140 onlap unit 100 , and unit 150 appears to overlap the fold scarp (Figure 5). Stratigraphic relations in trench exposures indicate displacement occurred after deposition of unit 100 and prior to the onlap sequence of units 110 to 150 . No reverse faults are evident within or below unit 100, which indicates folding as a predominant form of deformation in the past.

[34] The amount of vertical separation between the backlimb and forelimb, and style of deformation are strikingly similar between the 1999 and penultimate events. Structural relations in trench exposures indicate the penultimate earthquake, $E_{1}$, occurred before deposition of the first onlap sediments, unit 110, but after deposition of unit 100. These units yield radiocarbon ages of 1210-1440 and 1160-1310 A.D., respectively (Figure 6). We interpret the age of the penultimate event as occurring between 1160 and 1440 A.D.

\subsubsection{Evidence for an Earlier Earthquake, $\mathbf{E}_{2}$}

[35] We collected a series of shallow borings $\mathrm{C} 1$ through C4 (Figure 5) and excavated to a depth of $6.5 \mathrm{~m}$ across the fold scarp to identify evidence of earthquakes that occurred prior to the penultimate event. The loss of core from the borings during drilling and lateral facies change made it difficult to correlate sedimentary units across the fold scarp; nevertheless, stratigraphic relations show evidence for an 
earlier event, $E_{2}$. Relations such as depositional geometry, increasing vertical separation between the upper and lower fold limbs, and greater dip of unit surfaces across the fold scarp face were used to identify an event below the penultimate event horizon. Stratigraphic units below the penultimate event horizon show no evidence of an onlap sequence; however, units 70 to 50 slightly thicken in the forelimb. We interpret the thickening in these units to represent a depositional geometry smoothing a preexisting scarp. Vertical separation of units 70,60 , and 50 across the trench is not much greater than $3.0 \mathrm{~m}$, combined 1999 and penultimate vertical separation. These units were deposited after any earlier earthquakes.

[36] Evidence for event $\mathrm{E}_{2}$ comes from units 40 through 10. Surfaces of units 10 to 40 show greater dip across the fold scarp face than the penultimate event horizon (Figure 5). Unfortunately units $10-40$ are not exposed on the footwall as they are below the water table. We could not directly measure vertical separation. Unit 10 was clearly identified within boreholes $\mathrm{C} 1, \mathrm{C} 2$ and $\mathrm{C} 4$, and exhibits $3.8 \mathrm{~m}$ of vertical separation across the fold scarp. Units 20,30 , and 40 exhibit about $3.6 \mathrm{~m}$ of vertical separation across the trench. Subtracting $3 \mathrm{~m}$ of vertical separation identified at the penultimate event horizon yields 0.6 to $0.8 \mathrm{~m}$ of vertical separation of these units across the fold scarp. This increased vertical separation, and thickening of overlying units on the forelimb is strong evidence of an earlier event; however, further work is needed to better constrain the event horizon, age and amount of vertical separation from the event $\mathrm{E}_{2}$.

[37] Detrital charcoal collected from unit 10 yielded ages of 650-820 and 80-250 A.D. (Table 2). We interpret an older event before deposition of unit 10, before 650-820 A.D.

\subsubsection{Geomorphic Evidence of a Possible Earlier Earthquake, $\mathbf{E}_{\mathbf{3}}$}

[38] The geomorphology along the mountain front suggests the possibility of an earthquake that likely precedes all three events revealed in the excavation and boreholes. This earthquake $\left(E_{3}\right)$ would have occurred on a more easterly strand of the Chelungpu fault. The Holocene alluvial surface, $\mathrm{Qal}_{1}$ is bounded by a linear scarp to the west that parallels the 1999 scarp in this area (Figure 3). The older fault scarp is also similar in profile (Figures $4 b$ and $4 c$ ), except where modern drainages cross the surface. This scarp separates surfaces $\mathrm{Qal}_{1}$ and $\mathrm{Qal}_{2}$ and does not behave as a depositional feature in map view. The west edge of $\mathrm{Qal}_{1}$ is relatively straight and does not follow the curved contours of the $\mathrm{Qal}_{2}$ alluvial fan, nor does it follow the sinuous contours of the mountain front (Figure 3). In the field this scarp is continuous, and commonly the location of homes and temples. Construction of a small temple on the $\mathrm{Qal}_{1}$ surface revealed fine grain alluvial sediments below the surface. There are at least two explanations for the scarp west of the $\mathrm{Qal}_{1}$ alluvial surface: (1) there was a large event with uplift that outpaced burial by sedimentation or (2) there were numerous events with smaller vertical displacements occurring over a short period of time, so the rate of uplift outpaced sedimentation. The latter predicts off lapping depositional relations with the scarp bounding $\mathrm{Qal}_{1}$ on the west. Additional studies in this area would help determine the exact origin of this scarp.

\subsection{Kinematics of Fault-Related Folding}

[39] Trench wall exposures reveal (1) structural thickening of units 100 to 70 through the axis of the fold (Table 3 ), (2) bedding parallel shear between units of differing lithologies, and (3) a pop up structure with centimeter offsets within the upper $3 \mathrm{~m}$ of sediments. These structural complexities have made it difficult to account for the complete deformation field associated with each coseismic event.

[40] The trishear method of Erslev [1991] and Hardy and Ford [1997] provides an alternative method for restoring deformation across fault propagation folds that exhibit changes in forelimb-bedding thickness. In fault propagation folds, shear is initially concentrated in a fault zone. Shear spreads upward into overlying folds and is distributed in a triangular shape, when viewed in cross section. Trishear is defined as distributed, strain-compatible shear in a triangular shear zone viewed in profile [Erslev, 1991]. Parameters used in trishear modeling include (1) fault ramp orientation, (2) amount of displacement, (3) fault propagation to slip ratio, (4) trishear apical angle, and (5) fault tip position in $\mathrm{x}, \mathrm{y}$ coordinates [Allmendinger, 1998]. Trench wall exposures and borehole data define parameters of the fault and fold geometry and allowed us to apply Trishear 3.0 inverse models and retrodeform pre-1999 growth strata to a nearly planar surface (Figure 7) (R. W. Allmendinger, Trishear Numerical Modeling Code/Program, 2000). Inverse numerical modeling finds a best fit initial geometry matching a key bed within the defined parameters. Best fit parameters specified by the inverse model are used to run a forward model, deforming horizontal lines. Forward model results overlie observed fold geometry and show resulting misfit (Figure 7c). Given the parameters, the Trishear program estimates fault tip location beneath the surface, and propagation to slip ratio on the fault.

[41] The upper horizon of unit 90 is stratigraphically the highest continuous unit across the fold, and is the key bed used for inverse modeling. The best fit parameters using the trishear model place the fault tip at a depth of $6.78 \pm 0.3 \mathrm{~m}$ below the top of unit 90, or $7.18 \pm 0.3 \mathrm{~m}$ below the surface (Figure 7c). Error is calculated using the $96.4 \%$ correlation coefficient, a $3.6 \%$ misfit. Misfit of the observed data is very low because the fold geometry was generated from a detailed 1.0 by $0.5 \mathrm{~m}$ tiled photo trench $\log$, the dip of the fault was fairly well constrained by the borehole transect, and the upward termination of the fault tip is known to be below trench exposures but above its depth in boreholes.

[42] For the Shi-Jia site, the apex of the trishear zone is located at the tip of the fault. Trishear apical angle is $72^{\circ}$ (Figure 7b). The fault tip is $6.8 \mathrm{~m}$ beneath the modern ground surface, about half a meter below the trench exposures. The best fit fault ramp angle is $26^{\circ}$ east dipping, which is within error of the calculated fault dip of $27 \pm 2^{\circ}$ from the boring transect. (Total displacement of units is $9 \mathrm{~m}$ and the fault has propagated $19.8 \mathrm{~m}$.) The propagationto-slip ratio determines how rapidly the tip of the fault propagates upward relative to slip on the fault. The best fit model yields a propagation to slip ratio of 2.2, which implies that for every $2.2 \mathrm{~m}$ of upward propagation of the fault tip there is $1 \mathrm{~m}$ of slip on the fault itself. Folding is the predominant form of surface deformation at the Shi-Jia site; the rate of fault propagation must be lower than the rate of sediment accumulation. 


\section{a. Simplified tracing of trench units}
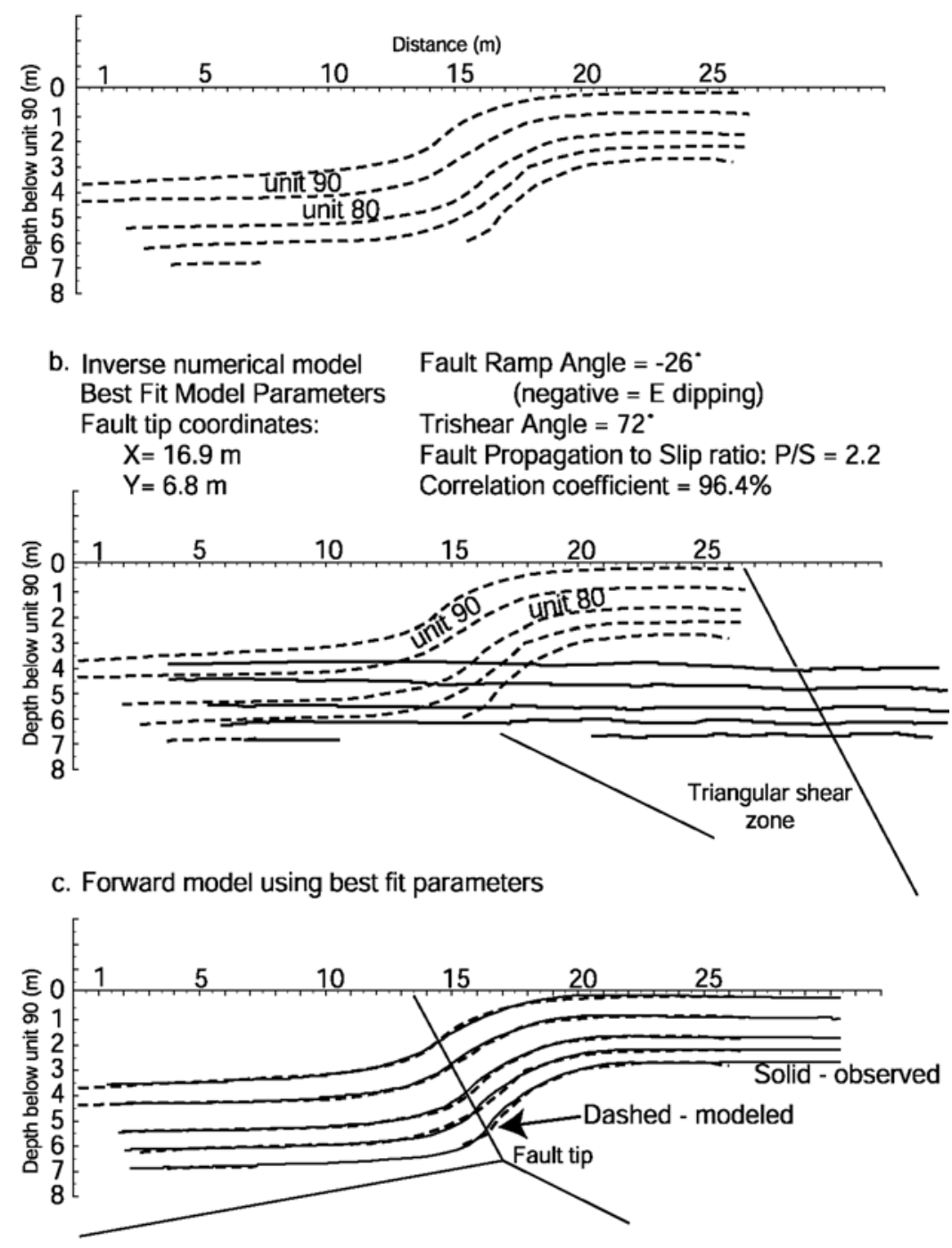

Figure 7. Inverse model of the Shi-Jia coseismic fold. (a) Simplified tracing of trench units. Dashed lines are simplified tracing along the tops of sedimentary units from the Shi-Jia trench log. The uppermost line is the top of unit 90, the first continuous undisturbed unit across the fold. (b) Inverse numerical model. Solid lines show the best restoration of units to a nearly planar surface; fold geometry is dashed. Best fit model parameters are shown. At the Shi-Jia site, the apex of the trishear zone is located at the tip of the fault. The propagation to slip ratio $(\mathrm{P} / \mathrm{S})$ determines how rapidly the tip line propagates relative to slip on the fault [Allmendinger, 1998]. (c) Forward model using best fit parameters. Observed geometry of units is shown as dashed lines, solid lines represent modeled unit horizons. Notice small differences between model and original tracing through fold. The model fits the original fold geometry to $96.4 \%$. Modeled using parameters from best fit restoration shown above with Trishear 3.0 Numerical Modeling (R. W. Allmendinger, Trishear Numerical Modeling Code/Program, 2000).

[43] Total horizontal displacement is calculated by subtracting the present profile length from the length of the trishear retrodeformed beds and yields a value of $4.2 \pm 0.2 \mathrm{~m}$ (Figure $7 b$ ).

[44] Dominguez et al. [2003] measured horizontal displacement across the fault by cross-correlating SPOT images before and after the earthquake. This study reports approximately $3.5 \pm 0.5 \mathrm{~m}$ of displacement perpendicular to the fault and $3.0 \pm 0.5 \mathrm{~m}$ of right lateral displacement in the vicinity of the Shi-Jia site. The trishear value $4.2 \pm 0.2 \mathrm{~m}$ of total horizontal offset is a good model to reconcile trench observations and independently measured horizontal shortening.

\section{Discussion}

\subsection{History of Events}

[45] Our study shows that near the center of the Tsaotun segment two great earthquakes of similar magnitude have occurred in roughly the last 560-840 years, the 1999 event, $\mathrm{E}_{0}$, and an older event $\mathrm{E}_{1}$ between 1160 and 1440 A.D. 


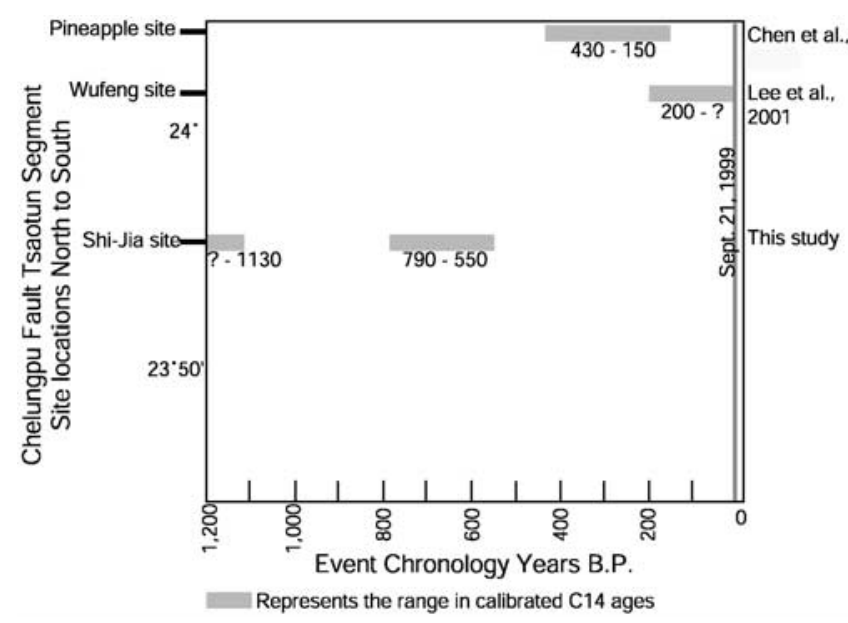

Figure 8. History of past rupturing earthquakes on the Tsaotun segment of the Chelungpu fault. Wufeng, Pineapple (Chen et al., submitted manuscript, 2007), and Shi-Jia paleoseismic sites are displayed along latitude of the Chelungpu fault. History of earthquakes at each site shown in years before present, using the 1950 standard. Wufeng and Pineapple sites show younger penultimate events than seen at the Shi-Jia site.

[46] Paleoseismic studies to the north of this study site show coseismic fold deformation accompanied with brittle deformation along a fault [Chen et al., 2004; Lee et al., 2001]. At the Pineapple site, the penultimate event occurred between 430 and 150 years B.P. (1520 to 1800 A.D.) (Figure 8) [Chen et al., 2004]. At Wufeng, the penultimate event occurred before 200 years B.P. (before 1750 A.D.) [Lee et al., 2001].

[47] The age of penultimate event differs between these sites (Figure 8). These paleoseismic studies indicate that along the Tsaotun segment of the Chelungpu fault, the timing of strain release and accumulation along strike is variable (Figure 8). This suggests that 1999-type events, rupturing the complete length of the Tsaotun fault segment, may not be characteristic on this segment of the Chelungpu fault.

\subsection{Sedimentation Rates}

[48] Trench wall exposures at the Shi-Jia site reveal onlap to overlap relations on the penultimate event horizon. The transition from onlap against the inferred ground surface of the penultimate event to overlap of the paleoscarp is revealed by the stratigraphic sequence. This onlap to overlap sequence suggests sedimentation rates at the Shi-Jia site are higher than uplift rates [Burbank and Vergés, 1994; Suppe et al., 1992]. Sedimentation rates in the last 1000 years B.P. have ranged from 2 to $3 \mathrm{~mm} / \mathrm{yr}$ (Figure 9), although, rates as high as $6 \mathrm{~mm} / \mathrm{yr}$ are permissible (Figure 9). Uplift rates of $1.8-3 \mathrm{~mm} / \mathrm{yr}$ (rate of vertical displacement) are considerably lower than sedimentation rates at this site. Therefore, recently, in this area fold scarps develop equally as fast as they are buried, obscuring geomorphic expression of prehistoric earthquake scarps.

\section{Conclusions}

[49] Excavations, borings, and geomorphic relations at the Shi-Jia site along the Chelungpu fault reveal a history of two or three recent surface ruptures culminating in the 1999 Chi-Chi $M_{w}=7.6$ earthquake and an earlier history of seismicity. Penultimate deformation in trench exposures is strikingly similar to 1999 deformation at the Shi-Jia site. Like the 1999 Chi-Chi earthquake, the penultimate caused fold deformation and about $1.5 \mathrm{~m}$ of vertical separation. The 1999 and penultimate events display similar slip magnitudes. The penultimate event is bracketed between 1160 and 1440 A.D.

[50] On the northern Tsaotun segment, two paleoseismic studies reveal much younger penultimate earthquakes [Lee et al., 2001; Chen et al., 2004]. A 1999-type event may not

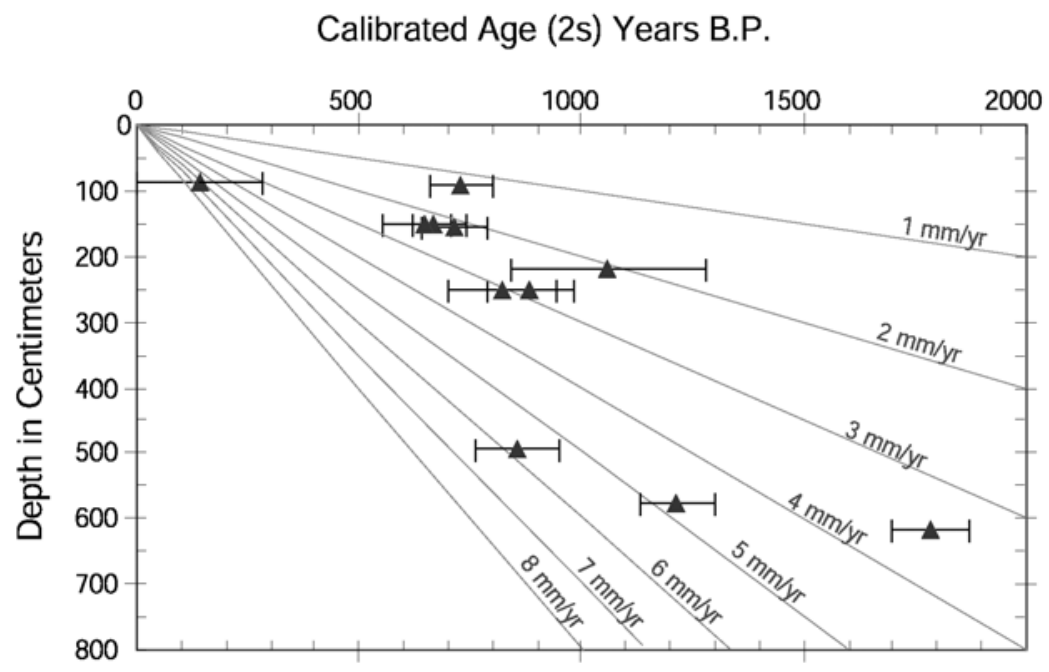

Figure 9. Age versus depth plot of ${ }^{14} \mathrm{C}$ samples from the Shi-Jia paleoseismic excavation. Selected sedimentation rates are shown as gray lines. 
be characteristic on the Tsaotun segment of the Chelungpu fault. This suggests that the amount of slip along strike has varied over time, or, the stratigraphic record at one or all sites is incomplete.

[51] Acknowledgments. We thank Shao-Yi Huang, Yu Wang, Chung Un Ray, Kun-Jie Lee, Bruce Shu, and NTU geology undergraduates for their assistance in the field. We also thank Karl Mueller, Rusty Ardoin, Jeff Schroeder, Rex Flake, Andy Miner, Linda Donohoo, John Hurely, and Laura Wissing for insightful discussions. We are also greatly appreciative to Fu-Jim-Hua for his superb logistical support and assistance in Taiwan. The authors thank Jan and Dave Streig for their fantastic support. The authors thank Keith Kelson, Jean-Philippe Avouac, Meghan Miller, Jeff Lee, and two anonymous reviewers for greatly improving the manuscript. This work funded in part by grants from the National Science Foundation (NSF) EAR 0107114 and the Central Geologic Survey of Taiwan and the National Science Council Taiwan. Independent summer research was also funded by the 2002 Summer Program in Taiwan and NSF/NSC graduate summer research fellowship to Streig.

\section{References}

Allmendinger, R. W. (1998), Inverse and forward modeling of trishear fault propagation folds, Tectonics, 17, 640-656.

Bonilla, M. G. (1975), A review of recently active faults in Taiwan, U.S Geol. Surv. Open-File Rep., 75-41, 43 pp.

Burbank, D. W., and J. Vergés (1994), Reconstruction of topography and related depositional systems during active thrusting, J. Geophys. Res., 99 , 20,281-20,297.

Chen, W.-S., et al. (2001), 1999 Chi-Chi earthquake: A case study on the role of thrust-ramp structures for generating earthquakes, Bull. Seismol. Soc. Am., 91, 1-9.

Chen, W.-S., K.-J. Lee, L.-S. Lee, D. J. Ponti, C. Prentice, Y.-G. Chen, H.-C. Chang, and Y.-H. Lee (2004), Slip rate and recurrence interval of the Chelungpu fault during the past 1900 years, Quat. Int., 115-116, 167-176.

Dominguez, S., J.-P. Avouac, and R. Michel (2003), Horizontal coseismic deformation of the 1999 Chi-Chi earthquake measured from SPOT satellite images: Implications for the seismic cycle along the western foothills of central Taiwan, J. Geophys. Res., 108(B2), 2083, doi:10.1029/ 2001JB000951.

Erslev, E. A. (1991), Trishear fault-propagation folding, Geology, 19, $617-$ 620.

Friedman, G. M., and J. E. Sanders (1978), Principles of Sedimentology, 792 pp., John Wiley, Hoboken, N. J.

Hardy, S., and M. Ford (1997), Numerical modeling of trishear faultpropagation folding and associated growth strata, Tectonics, 16, 5, $841-854$

Lee, J.-C., Y.-G. Chen, K. Sieh, K. Mueller, W.-S. Chen, H.-T. Chu, Y.-C. Chan, C. Rubin, and R. Yeats (2001), A vertical exposure of the 1999 surface rupture of the Chelungpu fault at Wufeng, Western Taiwan:
Structural and paleoseismic implications for an active fault, Bull. Seismol. Soc. Am., 91, 914-929.

Lee, J.-C., H.-T. Chu, J. Angelier, Y.-C. Chan, J.-C. Hu, C.-Y. Lu, and R.-J. Rau (2002), Geometry and structure of northern surface ruptures of the 1999, $M_{w}=7.6$ Chi-Chi Taiwan earthquake: Influence from inherited fold belt structures, J. Struct. Geol., 24, 173-192.

Ma, K-F, C-T, Lee, Y-B. Tsai, T.-C. Shin, and J. Mori (1999), The Chi-Chi Taiwan earthquake: Large surface displacements on an inland thrust fault, Eos Trans. AGU, 80(50), 605.

Ma, K.-F., T.-R. A. Song, S.-J. Lee, and H.-I. Wu (2000), Spatial slip distribution of the September 20, 1999, Chi-Chi, Taiwan, earthquake $\left(M_{w} 7.6\right)$ : Inverted from teleseismic data, Geophys. Res. Lett., 27, $3417-3420$.

Ota, Y., et al. (2001), Trenching study at the Tsaotun site in the central part of the Chelungpu Fault, Taiwan, West. Pac. Earth Sci., 1(4), 487-498.

Rubin, C. M., K. Sieh, Y.-G. Chen, J.-C. Lee, H.-T. Chu, R. Yeats, K. Muller, and Y.-C. Chan (2001), Surface rupture and behavior of thrust faults probed in Taiwan, Eos Trans. AGU, 82(47), 565.

Shin, T. C., K. W. Kuo, W. H. K. Lee, T. L. Teng, and Y. B. Tsai (2000), A preliminary report on the 1999 Chi-Chi (Taiwan) earthquake, Seismol. Res. Lett., 71, 24-30.

Stuiver, M., and H. A. Polach (1977), Discussion of reporting ${ }^{14} \mathrm{C}$ data, Radiocarbon, 3, 355-363.

Suppe, J. (1984), Kinematics of arc-continent collision, flipping of subduction, and back-arc spreading near Taiwan, Geol. Soc. China Mem., $6,21-33$.

Suppe, J. (1987), The active Taiwan mountain belt, in The Anatomy of Mountain Ranges, edited by J. P. Schaer and P. Rodgers, pp. 277-293, Princeton Univ. Press, Princeton, N. J.

Suppe, J., G. T. Chou, and S. C. Hook (1992), Rates of folding and faulting determined from growth strata, in Thrust Tectonics, edited by K. R. McClay, pp. 105-121, CRC Press, Boca Raton, Fla.

Yu, S.-B., H.-Y. Chen, and L.-C. Kuo (1997), Velocity field of GPS stations in the Taiwan area, Tectonophysics, 274, 41-59.

Yue, L.-F. J. Suppe, and J.-H. Hung (2005), Structural geology of a classic thrust belt earthquake: The 1999 Chi-Chi earthquake Taiwan $\left(M_{w}=7.6\right)$, J. Struct. Geol., 11, 2058-2083.

W.-S. Chen and Y.-G. Chen, Department of Geosciences, National Taiwan University, P.O. Box 13-318, Taipei 106, Taiwan.

L.-S. Lee, 567 Wesley Ave., Oakland, CA 94606, USA

S.-T. Lu, Central Geological Survey, P.O. Box 986, Taipei, Taiwan.

C. Madden, Earth Consultants International, 150 El Camino Real, Suite 212, Tustin, CA 92780, USA.

C. M. Rubin, Department of Geological Sciences, Central Washington University, 400 E. University Way, Ellensburg, WA 98926-7418, USA.

A. R. Streig and S. C. Thompson, William Lettis \& Associates, Inc., 1777 Botelho Drive, Suite 262, Walnut Creek, CA 94596, USA. (streig@) lettis.com) 